\title{
Audience-Oriented Forms of Performance in the 21st Century
}

\author{
Assoc. Prof. Dr. Ayrin Ersöz \\ Yildiz Technical University, Department of Music and Performing Arts, \\ ayersoz@gmail.com, aersoz@yildiz.edu.tr
}

\section{Doi:10.5901/ajis.2015.v4n1s2p31}

\begin{abstract}
The use of space in the mainstream performing arts is based on the division of the acting and performing spaces with an imaginary wall. The sharp division of the space by this invisible conventional border, also called the fourth wall, originated from the fundamentally distinct role definitions assigned to the audience and the actors. On the other hand, especially since midtwentieth century, due to the fast improvement in mass media technologies audiencing has widely shifted from the public space to the private space. Because of this shift the staging forms appropriate to the traditional space order became unresponsive to the needs of new acting and audiencing, and caused a search for alternative ways. In this respect, especially since the 1960's there have been many experiments examining both the acting and the audiencing activity from every aspect. These experiments invited the audience again into the public space, in search of new ways in which the audience could take an active role in a dynamic audience field. In these forms of performance, passive audience positions are completely abandoned and the role of the audience is reconstructed as an active element of the work itself. Since the beginning of the 21st century, there is a new trend in the Western performing arts, which is based on a participatory, interactive and immersive performance approach. Especially in the immersive performance approach, the audience is invited to a multi-sensory experience. To the extent that they actively participate in the experience, they gain the freedom of creating different audiencing forms and even reconstructing the plot. In these kinds of forms, the audience is invited to almost a realistic experience in spaces constructed to create this realistic feeling. Providing a holistic perception and participation, this experience goes beyond the conventional audiencing forms based on the audio and visual senses, by addressing and stimulating the olfactory, gustatory, and tactile senses. It also allows the audience to participate in the movements of the performers as well as follow them in the almost realistically constructed performance spaces. As today's audience is accustomed to being active players on the internet and creating worlds at their fingertips on virtual games, new narratives that bring together the audience and the performing arts are thus constructed.
\end{abstract}

Keywords: audience, performing arts, performing space, immersive practices

It is apparent that in performance-based arts, mainly theatre and dance, the conventional forms of expression and narratives are increasingly receiving less interest by the audience. In this, it is certain that new media produced through changes in technology are certainly of primary importance. Internet, with its features of the nonlinear structure of World Wide Web offering hyperlink possibilities, giving opportunities to be participatory and interactive, channelling to making comment contribution, is marked as a revolutionary medium of today. The character of this "deep media" that the internet creates is defined as immersive. (Rose, 2011: 2-3) Before these developments were reflected in the performing arts, there were clear cut definitions that determined some important features of performance as theatrical space and audiencing. The space in the mainstream performing art examples gives a clear placement for the performers and the audience. Theatre as problematized by McAuley ". . . consists of human beings in a defined space watched by other human beings, and it is this reality that constitutes the basic apparatus of theatre" (McAuley, 1999: 245). The theatrical reality here lies on the fact that there is a need for space where the audience and the performers meet in the live event, and in this space the already defined roles and their placements are assigned. This reality creates an imagined but also clear and unquestionable cut of the theatrical space, where the theatrical experience is shared by both parties, the performers and the audience in their definite placement of the space. This experience is possible on the previously negotiated casting of their roles; performers are there to act on the slightly elevated, lit platform, the stage; and the audience is seated across the stage in the dark auditorium watching and hearing the actions of the performers. Performers are acting in order to be seen, audience is silenced both vocally and physically in order to be able to see and hear everything on stage. In all mainstream theatre or opera house building around the world, we can see the audience sitting in the dark hall in the auditorium, facing one direction gazing the framed fictional world revealing itself in front of their eyes, in this fixed and atrophied position. This space mostly named as the proscenium stage "creates a theatre of illusion" with the tendency "to preserve the strong distinction between life and art..." Foster (1986: 60) 
"The proscenium theatre emphasizes the separation of audience and the performance by situating the action on the stage in a different realm from that of the viewers. The architecture delineates a functional role for viewers - as observers who sit facing in one direction toward the stage - and for performers - as residents of the framed, boxlike structure of the stage... the proscenium arrangement also implies a single perspective from which the dance is to be viewed and the hierarchy of optimum locations in the auditorium. " (Foster, 1986: 60-61)

The proscenium arch functions as a frame, where the moving bodies of the dancers through the choreography or the actions of the actors through the dramaturgical design in the plays create the framed images resembling the live pictures bound to the the rules of perspective. The audience as the viewers of the art in the galleries or the viewers of the cinema are in front of the framed image, watching this fictional reality revealing itself in front of their eyes. The images to be presented are on stage, and what is yet to be seen is cast behind the wings/the frame.

"The Western mainstream theatrical experience, from the Venetian Opera House to New York's Broadway, is gauged to enforce that separation. This method of viewing performance is further reinforced by our experiences of cinema. The huge screen acts as an opaque proscenium, where applause, derision or complete indifference is unable to affect the performance. Again the audience sits in a darkened space watching larger-than-life faces on the lighted screen. "(Popat, 2010: 2)

The position of the audience looking at the event on the stage is problematized by Ranciere as the opposite of knowing. The audience does not know the conditions producing the appearance they are looking at. Ranciere also casts the looking of the spectator opposite from acting "[h]e who looks at the spectacle remains motionless in his seat, lacking any power of intervention. Being a spectator means being passive. The spectator is separated from the capacity of knowing just as he is separated from the possibility of acting. " (Jacques Rancière, 2007) In the mainstream theatre understanding, be it in the proscenium stages or in the smaller theatres, or even in the blackbox theatre spaces, there is this bodily passivity of the audience expected for the performance's sake. The actions long rehearsed by the performers are awaiting this silent crowd in the auditorium to sit and be quiet to come alive. There is so much effort spent on the part of the performers before the premiere, the days and nights of exhaustion, desperation, and boredom of the endless repetitions, corrections and adjustments of an performative work of art to be created. On the night of the premiere the dancers, actors, performers in general are waiting behind the wings with excitement and nervousness to step on stage and perform without mistake, with expectations of high performance, they want to be good, they want the work to be liked. The part of the audience is clear; sit quiet and enjoy, hopefully like the performance. Although passive in its first appreciation, the role of the audience is very important. The performance created is for the audience to see, hear and appreciate.

"On entering the majority of theatres in the Western world, one expects to see the proscenium arch ornately framing the stage and blatantly dividing the performance space from the viewing area. Performer and audience member are situated on either side of this getaway between the lighted virtuality of the performer and the darkened, suspended reality of the viewer. " (Popat, 2010: 1)

Bertolt Brecht was an important figure in trespassing this invisible border between the actors and spectators, and emancipating the audience from its passive position. Influenced by the forms used in the Chinese theatre, Brecht developed the concept of alienation, as opposed to the identification acting techniques used in the Western theatre. His theatre can be seen as an attempt to make the invisible border apparent by criticising and problematizing it. In Brecht's Epic theatre, the audience was forced to come out of their passive roles of identifying with the characters, of the illusionary world created in the traditional Western theatre. He used different aspects of the theatre in juxtaposition to each other creating contrary moods conflicting the audience's perceptions, where they are invited to develop their own thoughts and reconcile the events on the stage. In his theatre the audience is alienated from the events on the stage, clearly reminded of the events' fictionality.

The concepts developed by Brecht were also used in the tanztheater of Pina Bausch, who first introduced a radically different approach to dance in the 70s' Germany to an audience accustomed to classical ballet performances. The choreographies of Bausch first problematized the notions of beauty in dance by putting on display the tired, sweaty body of the dancers, revealing the physical truth of the dancers which has long been concealed from the audience's gaze. The dancers were no longer hiding the physical effort behind a smile, while executing difficult movements as it was and still is expected in ballet. They were not subjects of fairy tales, creating illusions on stage to be admired; they resembled the hard working laborers of the country with their strong limbs and almost naked bodies. 
With her established name in the field, Bausch also made her dancers talk to the audience, acknowledging their existence in the darkened auditorium. The trespassing of the invisible border was done by the performers, facing the audience and addressing them directly, performing for them, making clear that the performances were created for the audience. They were breaking the illusionary wall by questioning the established roles of the dancers and performers. In the tanztheater of Pina Bausch the audience is invited to a place where they are aware of their existence and also acknowledge their traditional role of passively gazing the action on stage from their seat in the dark hall, open to be impressed.

The twentieth century saw many theatre experiments where not only the role of the audience but also the main tools of the Western representation discourse present in the classical idea of theatre were questioned: the plot, the character, the space, etc. were problematized. Nevertheless, space as the physical framework for holding the theatrical experience was one of mostly problematized aspects in the past thirty years as stated by McAuley:

". . . there has been a significant trend over the past thirty years for performance practitioners to abandon the non-place of the stage and the controlled relationship between stage and auditorium of the traditional theatre building, and to locate their performances in the other sites within the social space of the community. . . there has been a significant increase in this kind of performance over the same period that critics and theorists in many other disciplines were developing new understandings of the spatialised nature of human culture. Theatre practitioners were, thus, already making a major contribution to what I have called the 'placial turn' which is perhaps to be expected from an art form that has for centuries been playing so profoundly with its own spatiality. " (McAuley, 2006: 17).

Experimenting with different spaces in the performing arts increased with the second half of the 20th century searching for new ways to connect the body of the performers with the space the performance is held and also with the role of the audience. Not only the trespassing of the invisible wall between the audience and performers was realized and widely practiced, but also the walls of the theatres were metaphorically demolished. The frame of the proscenium arch was considered as a limiting boundary for new expectations of the world outside. The streets, buildings, town squares, museums, docks, factories, etc. were the new spaces opened to be explored and experienced for the new democratic movements within the performing arts, be it theatre or dance.

McAuley, in his introduction to the book Unstable Ground Performance and the Politics of Space, discusses the needs and the consequences of moving the performances outside the defined spaces in the sites "marked by their own histories of occupation," where the artists and spectators not only experience these spaces in new ways but also are "obliged to engage in new ways with the political issues that seem to be an inevitable consequence of being in place. " (McAuley, 2006: 17)

"The reality of place ineluctably brings with it issues of ownership and these in turn involve issues of power, rights (of exclusion and inclusion), and multiple often conflictual histories of occupation and exploitation. Places raise questions about memory and about group and individual identity: who we are intimately bound up with where we are, and where we come from. Performing in place brings to the fore the nature of inhabitation: what it means to live in/with a place, and what it means to be inhabited by a place. " (McAuley, 2006: 17)

Choreographer William Forsythe expanded the limits of space and the dance discipline by introducing the concept of dance installations to the field of choreography. His expanding the language of ballet, moving the walls that strictly define its technique, is his distinguished signature in the dance world. Merging dance with art, bringing dance into the spaces defined for objects of art, like museums and art galleries are his innovations in the dance world. One of his "choreographic objects" titled "Nowhere and Everywhere at the Same Time No. 2," was presented in 2014 at the Circus Street Market as part of the Brighton Festival, an annual arts festival in England, where, in an old municipal market space filled with hundreds of suspended pendulums that swing in timed sequences, visitors are invited "to move through the space they are forced to duck, dodge, and dart through the rows of swinging weights resulting in an impromptu dance. Forsythe is known for his unique blend of choreography and artwork where the viewer often becomes a participant in his interactive installations. " (http: //www. thisiscolossal. com) Forsythe merges dance and choreography with art, and brings them out of their theatrical spaces into spaces that are defined for arts, like museums and galleries. He also brings them to places that do not necessarily represent artistic practices, like storehouses and markets. His project Human Writes, created for the 50th anniversary of the Universal Declaration of Human Rights, was presented in the 17th International Istanbul Theatre Festival in a storehouse. In this project, the space was not only removed from the traditional division for acting and viewing but also the audience was invited to participate in the act of the performers. The audience was invited to become active participants of the hopeless effort of the dancers in their writing of the human rights declaration on the 
white tables with black charcoal. This project, acting almost as a participatory theatre, also is a form to rebind the social ties where the collective meaning making can be practiced and the problems can be solved in the common ground.

The suggestions for the staging forms in the performing arts, in other words the spacing propositions brought for meeting the performance with the audience are directly problematizing the role of the audience in the ontological structure of the performance. The audience is freed of his voyeur (Guy Debord, 1983) position and becomes the active protagonist in the meaning making of the piece. There are numerous ways and forms of practicing the audience involvement in the performing arts. In the performances using the term immersive the audience involvement is practiced in various ways. As indicated by Josephine Machon in her book Immersive Theaters, Intimacy and Immediacy in Contemporary Performance (2013), the traditional and immersive practices present a completely different range of experience for their audiences; a short summary of her extensive comparison is given here as follows: In traditional theatre, the audience is expected to enter the space from the street via the main door, while in the immersive theatres the audience may have an extended and intriguing journey to get to the location. Through this journey, the audience is aware that they are taken out of their comfort zone. After entering the performance space, the traditional audience in the traditional auditorium may chat with friends, check their phone or read the program, while waiting for the show to start, as opposed to the audience in the immersive theatre who are separated from their friends. They may enter the space where the performance has already begun, they may even be partnered with a stranger and asked to rely on that person during their experience. They do not know exactly what to expect. In traditional theatre, after the lights are dimmed and the curtain is raised or the lights on the stage are lit, the audience becomes quite; another world reveals itself to them. However, the audience of the immersive theatre is already surrounded by a different world; they are out of their comfort zone, highly aware of the details of the space they are in, their senses heightened. While performers are performing in their world in front of the audience in the traditional theatrical setting, the performance is completed with no specific reference to the audience. In the immersive theatre, the audience may be asked to play a role, wear a masque and be anonymous but visible and physical. The audience is in a different world with its own rules, where they are active and engaged in the actions; following performers, passing through streets, into the rooms, wandering around details of the created environments, feeling almost responsible of the action happening around them, surrounded by this world. At the end of the performance, in traditional theatre, the lights of the auditorium turns on the curtain call bow and the audience applaud; however, there is no bow or an occasion to applaud in the immersive theatres--the world left behind may feel as if it still continues (Machon, 2013: 54-55).

In the immersive theatre, the audience enter the realm of "viveur" as stated by Claire Bishop, extending the "voyeur" theory of Guy Debord (Bishop in Machon, 2013: 72). The audience is brought into the heart of the experience, contrary to the one in the traditional theatre, where they are cast out of the frame of action. The audience is gaining a new subjective position, where they are no longer the outside observers, but are in the play directly, experiencing the action and the space. ". . . You are part of it, rather than looking on fundamentally distinct. " (Trueman in Machon, 2013: 72)

"Juxtaposed with participation being extorted in this way, however, is the fact that immersive theatre audiences are not bound to observe from any one site, such as a theatre auditorium. Rather, should they be willing and able to take advantage of the kinds of movement demanded of them, audiences may reap the benefit of multiple viewing perspectives in what may well be several viewing positions. In this respect, it is clear that immersive theatre finds its precursors in promenade and sitespecific/-generic/-sympathetic theatre. " (Alston, 2013: 4)

In audience-oriented works, whether they be defined participatory, interactive or immersive, the audience is cast in the center of the action. Instead of the traditional observer, the audience in these kinds of performances gains an active role, where they are the trigger of the action, where in some cases there is no action unless the audience causes one; this is especially the case in interactive performances.

This new theatre proposition was put forth by a London based theatre company Punchdrunk founded by Felix Barrett in 1999. With this new term "immersive", they freed the audience from their atrophied position bound to their seats, and assigned to them a more active and physical new position. Punchdrunk invites the audience to a multi-sensory experience. The company director Felix Barrett gives an illuminating description of his understanding for what immersive applies for in their work:

"It's the empowerment of the audience in the sense that they're put at the center of the action; they are the pivot from which everything else spins. It's the creation of parallel theatrical universes within which audiences forget that they're an audience, and thus their status within the work shifts. " (Barret in Machon 2013: 159) 
The company occupies large industrial spaces such as warehouses, art centres and abandoned buildings to build a real like environments inside them, a hotel as McKittrick hotel in the production Sleep No More or like Temple Studios in The Drowned Man. The company often uses the entire space for staging its performances where the space is transformed in every little detail to create the world of the performance in which world the audience is invited to explore by wandering around its halls, rooms and corridors. As defined by Papaioannou "the mises en scène of Punchdrunk can be understood as ephemeral landscapes that are produced by the co-existence of performers and spectators within a performative space; that is, a space that functions as a huge 'living' installation, or as an assemblage of tiny ones. " (Papaioannou, 2014: 163)

Bishop draws our attention to the continuities between the motivations behind the participatory works of $60 \mathrm{~s}$ and today, where she sets forth the three main concerns: creating an active subject, authorship and restoration of community (Bishop, 2006: 12). She defines the active subject as "one who will be empowered by the experience of physical or symbolic participation... able to determine [his] own social and political reality. " as for authorship she reminds us that ". . ceding some or all authorial control is conventionally regarded as more egalitarian and democratic than the creation of a work by a single artist..." while "[c]ollaborative creativity is therefore understood both to emerge from, and to produce, a more positive and non-hierarchical social model. " She also explains the issue of community that is "[0]ne of the main impetuses behind participatory art has therefore been a restoration of the social bond through a collective elaboration of meaning (Bishop, 2006: 12).

As today's audience is accustomed to being active players on the internet and creating worlds at their fingertips on virtual games, new narratives that bring together the audience and the performing arts are constructed. These new forms of performance not only bring the audience and performers into the new perspective, but they also remind us of the importance of rebinding the ties that create the community and the "public" of the public sphere. New ways of participation in the public sphere created through these kinds of performances are open for a no longer passive audience invited to collaborate and actively participate in the meaning making of the performance, and be active in the creation of the narrative by making personal and deliberate choices. Immersive theatre became a tool for conceptualising new forms of performative presence that break the rules of linear narrative, passively perceived through sight and hearing of an inactive audience. This theatre suggests new subjectivities and definitions for the roles of performers and audience through their submergence into the new theatrical environment created.

\section{References}

Alston, Adam. , (2013), Audience Participation and Neoliberal Value: Risk, agency and responsibility in immersive theatre Published online: 14 Jun 2013. http: /lepubs. surrey. ac. uk

Bishop, Claire, (2006), Participation, London The MIT press, Cambridge, Massachusetts.

Debord, Guy. , (1983), Society of the Spectacle, transl. Ken Knabb, Rebel Press.

Foster, Susan Leigh. , (1986) Reading Dancing: Bodies and Subjects in Contemporary American Dance, Berkeley and Los Angeles, University of California Press.

Machon, Josephine. , (2013) Immersive Theaters, Intimacy and Immediacy in Contemporary Performance, UK, Palgrave Macmillan.

McAuley, Gay. , (1999) Space in Performance: Making Meaning in the Theatre Ann Arbor (Mich. ), University of Michigan Press.

McAuley, Gay. , (2006) Unstable ground: Performance and the Politics of Place, ed. Gay McAuley, Brussels, P. I. E. Peter Lang.

Papaioannou, Spyros. , (2014) Immersion, 'smooth' spaces and critical voyeurism in the work of Punchdrunk, Studies in Theatre and Performance, 34: 2, 160-174.

Popat, Sita. , (2010) Invisible Connections: Dance, Choreography and Internet Communities, Routledge, New York, NY.

Rancière, Jacques. , (2007) The Emancipated Spectator, Excerpt from Art Forum, March 2007 http: //ranciere. blogspot. com. tr/2008/05/emancipated-spectator. html

Rose,Frank. , (2011) The Art of Immersion: How the Digital Generation Is Remaking Hollywood, Madison Avenue, and the Way We Tell Stories, USA, W. W. Norton. 
